\title{
Clipping Height and Frequency Influence Growth Response of Nitrogen-Fertilized Blue Grama
}

\section{ERMIAS BEKELE, REX D. PIEPER, AND DON D. DWYER}

Highlight: A greenhouse study with two clipping heights (1- and 2-inch stubble heights) and two clipping frequencies (every 10 and 20 days) showed that blue grama was able to make use of nitrogen fertilizer much more efficiently when unclipped than when clipped. Both clipping heights and clipping intervals decreased shoot and root weights on fertilized plants compared to fertilized and unclipped plants. The effect of clipping on unfertilized plants was much less drastic than on fertilized plants.

Range fertilization is becoming an important practice on many areas (Vallentine, 1971). Several studies have shown that nitrogen fertilization can increase herbage production of blue grama (Bouteloua gracilis (H. B. K. ) Lag. ex Steud) (Dwyer, 1969, and 1971; Goetz, 1970; and Rogler and Lorenz, 1957). Since blue grama is such a widely distributed and valuable forage species, range fertilization may have widespread economic benefit.

Most past field studies of blue grama fertilization were conducted on small plots protected from grazing. To devise grazing schemes for maximum response from the fertilization, information is needed about the response of fertilized blue grama to defoliation or grazing. Few studies have been conducted on blue grama to determine how clipping influences the utilization of nitrogen fertilizer. Dwyer (1969) reported that blue grama clipped every 10 days at a 1 -inch stubble height did not respond to applications of $60 \mathrm{lb}$ of nitrogen per acre, while plants clipped to a 2 -inch height at the same interval showed significant response. However, little information is available about blue grama response in relation to clipping height and frequency under fertilization. Consequently, the objective of this study was to determine effects of clipping height and frequency on growth response of nitrogenfertilized and unfertilized blue grama.

\section{Methods and Procedures}

The study was conducted in a greenhouse from May to August, 1971. Uniform cores of blue grama, 3 inches by 3 inches, obtained from the Fort Stanton Cooperative Range Research Station, New Mexico State University, were placed in gallon waxed-paper pots filled with equal amounts of fine sandy soil.

A $2 \times 2 \times 2$ factorial experiment, plus two other treatments, was used in a randomized block design with four replications. Treatments included two levels of clipping frequency (clipped every 10 and 20 days and one series clipped at the end of the study), two levels of nitrogen fertilizer ( 0 and $60 \mathrm{lb} / \mathrm{acre}$ of nitrogen), and two stubble heights (1 and 2

Authors are former graduate student, associate professor of range science, and former professor of range science, New Mexico State University, Las Cruces. Don Dwyer is now head, Department of Range Science, Utah State University, Logan.

The research appears as Journal Article 481, Agricultural Experiment Station, New Mexico State University, Las Cruces.

Manuscript received August 2, 1973. inches) and a control which was not fertilized and was clipped only at the end of the experiment.

Fertilizer treatments were applied in solution to insure uniform application. At the end of the experiment, all plants were clipped to a $1 / 2$-inch stubble height. Root weights were obtained by washing the roots from each pot with a gentle stream of water over a fine mesh hardware cloth. The roots from each pot were then dried and weighed. Data analysis included an analysis of variance and Duncan's Multiple Range Test for comparing means when the analysis of variance indicated a significant difference among treaments.

\section{Results and Discussion}

The analysis of variance indicated significant differences among treatments for both shoot and root weights (Table 1). The main effects of clipping interval and fertilizer also significantly influenced shoot and root weights while the effects of clipping heights were more pronounced on shoot weights than on root weights (Table 1).

Fertilization significantly increased both shoot and root weights. However, the interaction of clipping interval and fertilization was also significant for shoot weight and root weight. Clipping every ten days significantly reduced shoot and root weight of fertilized plants, but not unfertilized plants (Figs. 1 and 2).

The interaction of clipping height $X$ fertilization was also significant $(\mathrm{P}<.05)$ for shoot weight but not for root weight. Under fertilization, clipping to a one inch height significantly reduced shoot weight over that for plants clipped to a two inch stubble height (Fig. 1). However, there was no significant

Table 1. Summary of analysis of variance for shoot, root, and total (Shoot and Root) production of blue grama under different clipping frequencies (I), clipping (H), and nitrogen fertilization (F).

\begin{tabular}{|c|c|c|c|c|}
\hline \multirow[b]{2}{*}{ Source } & \multicolumn{4}{|c|}{ Mean squares } \\
\hline & D.F. & $\begin{array}{c}\text { Shoot } \\
\text { production }\end{array}$ & $\begin{array}{c}\text { Root } \\
\text { weight }\end{array}$ & $\begin{array}{l}\text { Total } \\
\text { (shoot and } \\
\text { root) pro- } \\
\text { duction }\end{array}$ \\
\hline Total & 39 & & & \\
\hline Replications & 3 & & & \\
\hline Treatments & 9 & $30.5 * * *$ & $15.7 * * *$ & $40.0 * * *$ \\
\hline Interval (I) & 1 & $7.1 * * *$ & $9.5 * * *$ & $33.1 * * *$ \\
\hline Height $(\mathrm{H})$ & 1 & $6.8^{* * *}$ & $1.5 *$ & $14.7 * * *$ \\
\hline Fertilizer (F) & 1 & $118.0^{* * *}$ & $8.8 * * *$ & $191.4 * * *$ \\
\hline $\mathrm{I} \times \mathrm{H}$ & 1 & 0.6 & 0.1 & 0.5 \\
\hline $\mathrm{I} \times \mathrm{F}$ & 1 & $2.7^{* *}$ & $3.2 * * *$ & $11.7^{* * *}$ \\
\hline $\mathrm{H} \times \mathrm{F}$ & 1 & $2.7 * *$ & 0.6 & 0.8 \\
\hline $\mathrm{I} \times \mathrm{H} \times \mathrm{F}$ & 1 & 0.1 & 0.6 & 0.2 \\
\hline Unclipped F vs Unfert & 1 & $127.4 * * *$ & $47.1 * * *$ & $47.1 * * *$ \\
\hline Unclipped vs clipped & 1 & $8.7 * * *$ & $69.7 * * *$ & $60.9 * * *$ \\
\hline Residual & 27 & 0.6 & 0.4 & 0.5 \\
\hline
\end{tabular}

* Significant at $P<.10$.

**Significant at $P<.05$.

*** Significant at $P<.01$. 


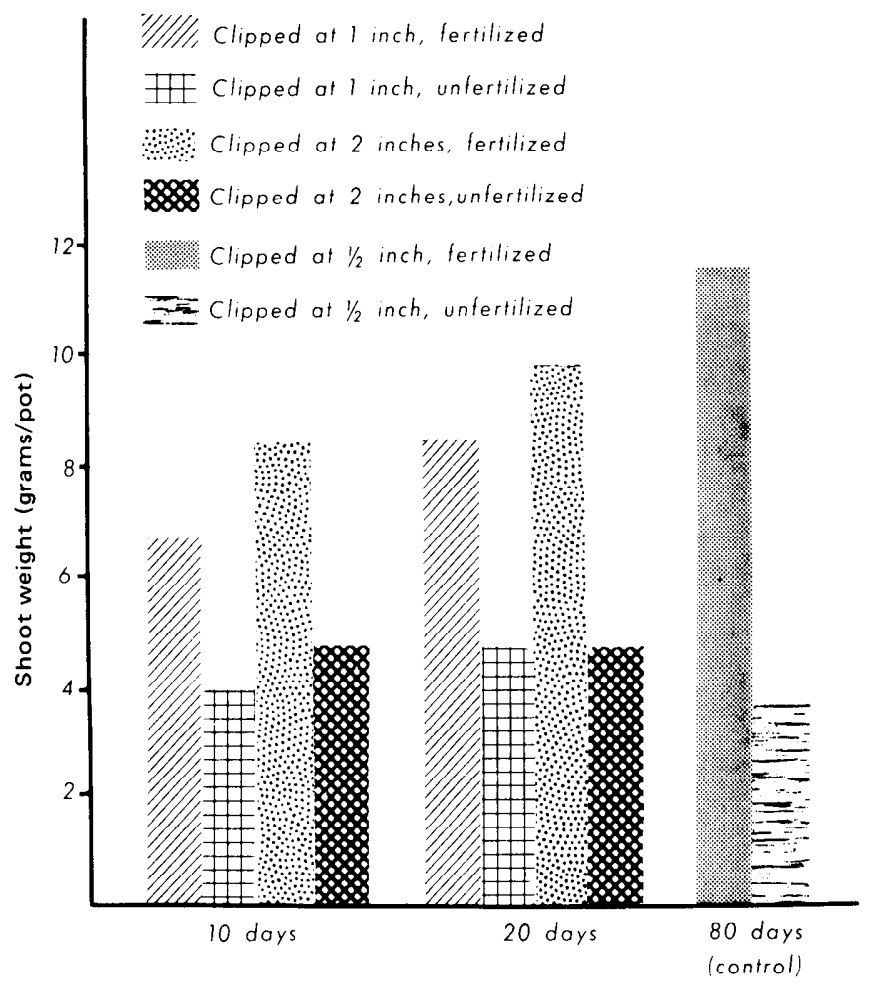

CLIPPING FREQUENCY

Fig. 1. Production of shoots of fertilized and unfertilized blue grama at different clipping frequencies and heights.

difference in production between unfertilized plants clipped at one and two inch stubble heights. For roots, clipping height influenced weights at only 0.10 level (Fig. 2).

The interaction of clipping interval $X$ height was not significant for either shoot or root weight (Table 1). Both clipping intervals and heights reduced shoot and root wcight over unclipped, fertilized plants. However, clipping to a two inch stubble height every 10 days and to both a one and two inch height every 20 days stimulated shoot production compared to control plants (Fig. 1).

Root: shoot ratios were lower under fertilization than under no fertilization for plants clipped every 10 days and for those clipped at 2 -inch stubble heights every 20 days (Table 2). Apparently, fertilization increased shoot production more than root production. Only plants unfertilized and unclipped had a root: shoot ratio exceeding 1 . Plants clipped every 20 days had a higher root: shoot ratio than those clipped every 10 days. Those plants clipped at a 2-inch stubble height had higher root: shoot ratios than those clipped to a 1 -inch stubble height.

Table 2. Root:Shoot weight ratios of nitrogen-fertilized (F) and unfertilized (U) blue grama grass clipped at different clipping frequencies and clipping heights.

\begin{tabular}{|c|c|c|c|c|c|}
\hline \multirow{3}{*}{$\begin{array}{l}\text { Clipping } \\
\text { frequency }\end{array}$} & \multicolumn{4}{|c|}{ Clipping height } & \multirow[b]{3}{*}{ Average } \\
\hline & \multicolumn{2}{|c|}{1 inch } & \multicolumn{2}{|c|}{2 inch } & \\
\hline & $\mathrm{F}$ & $\mathrm{U}$ & $\mathrm{F}$ & $\mathrm{U}$ & \\
\hline 10 days & 0.37 & 0.54 & 0.38 & 0.57 & 0.47 \\
\hline 20 days & 0.54 & 0.49 & 0.46 & 0.70 & 0.55 \\
\hline Average & 0.46 & 0.52 & 0.42 & 0.64 & \\
\hline
\end{tabular}

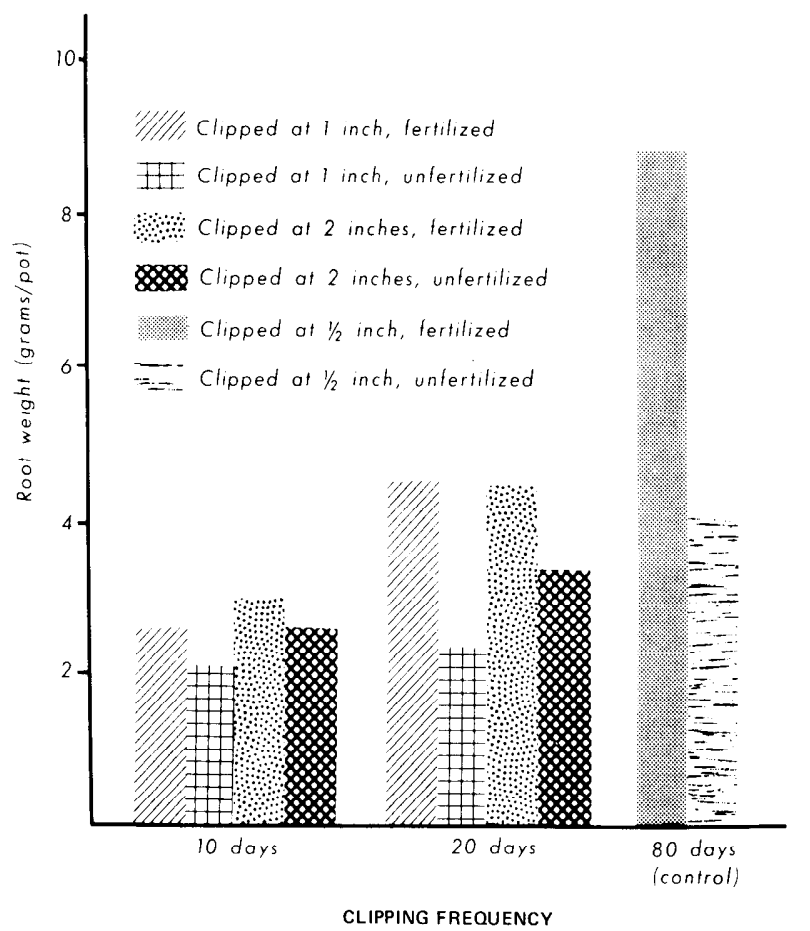

Fig. 2. Production of roots of fertilized and unfertilized blue grama at different clipping frequencies and heights.

\section{Application of Findings}

Under fertilization, both increased clipping frequency and lower clipping height reduced shoot growth substantially over plants clipped at less frequent intervals and at higher stubble heights. These data indicate that if photosynthetic tissue is removed, blue grama cannot utilize additional nitrogen added by fertilizer as suggested by Dwyer (1969) and Reed and Dwyer (1971). There was little difference in the reduction of shoot weight when clipping interval was compared to clipping height. The data suggest that heavy grazing intensity may be very important in reducing the efficiency with which blue grama utilizes nitrogen fertilizer.

Root growth decreased with increased frequency of clipping, although fertilizer increased root weights.

If nitrogen is to be applied to blue grama ranges in an effort to increase production of dry matter, care should be taken to insure that grazing is minimal during the initial growth stage. In fact, complete rest from grazing during the early growth stage would provide the best opportunity for blue grama to respond to increased fertility.

\section{Literature Cited}

Dwyer, Don D. 1969. Greenhouse production of blue grama as influenced by clipping and nitrogen fertilization. New Mex. State Univ. Agr. Exp. Sta. Bull. 549.

Dwyer, Don D. 1971. Nitrogen fertilization of blue grama range. New Mex. State Univ. Agr. Exp. Sta. Bull. 585.

Goetz, Harold. 1970. Growth and development of northern Great Plains species in relation to nitrogen fertilization. J. Range Manage. 23:112-117.

Reed, Jerry L., and Don D. Dwyer. 1971. Blue grama response to nitrogen and clipping under two soil moisture levels. J. Range Manage. 24:47-51.

Rogler, George A., and Russell L. Lorenz. 1957. Nitrogen fertilization of nor thern Great Plains rangelands. J. Range Manage. 10:156-160.

Vallentine, John F. 1971. Range developments and improvements. Brigham Young Univ. Press. Provo, Utah. 516 p. 